\title{
Аналіз основ та вироблення рекомендацій щодо початку роботи із системою доктринального забезпечення Сухопутних військ США в контексті приведення доктринального забезпечення 3бройних Сил України до стандартів НАТО
}

\author{
Віктор Россійцев ${ }^{*}$ А \\ А Національний університет оборони України імені Івана Черняховського, проспект Повітрофлотський, 28, м. Київ, 03049, Україна
}

Received: October 04, 2020 | Revised: October 25, 2020 | Accepted: October 31, 2020

DOI: $10.33445 /$ sds.2020.10.5.7

\begin{abstract}
Анотація
Стаття буде цікавою для фахівців складових сил оборони які займаються їх розбудовою та працюють над вивченням і запровадженням сучасних стандартів і принципів провідних країн членів НАТО. США $€$ передовою країною НАТО та їх збройні сили мають значний вплив на сучасний стан і перспективи цього військово-політичного блоку. Стаття сфокусована на доктринальному забезпеченні СВ США. За рівнем важливості, Доктрини СВ США можливо прирівняти до керівних документів рівня окремої складової сил оборони. Наразі система доктринального забезпечення Сухопутних військ США відкрита і знаходиться у вільному доступі у мережі інтернет. Тисячі доктринальних та інших військових керівних публікацій СВ США дають вичерпний перелік відповідей на питання щодо сучасних стандартів функціювання збройних сил у мирний та воєнний час. Спектр питань варіюється від порядку взаємодії між різними складовими сил оборони до принципів здорового харчування та сну окремого військовослужбовця.

Стаття написана в контексті реформи системи доктринального забезпечення Збройних Сил України. Реформа передбачає розробку до кінця 2020 року 272 нових доктринальних документів із урахуванням стандартів НАТО та досвіду Операції Об'єднаних сил (Антитерористичної операції) ООС (АТО) на сході України. Таким чином, перед розробниками нових доктрин стоїть завдання у короткі терміни вивчити і узагальнити досвід ООС (АТО), вимоги як чинних національних керівних документів так і стандартів провідних країн членів НАТО та підготувати на їх основі такі нові доктринальні документи ЗС України які дозволять ефективно виконувати покладені на них завдання. Однак робота із доктринальними документами іншої країни, крім знання іноземної мови та відповідної військової термінології, також потребує знання основ роботи із ними. Стаття надає мінімальний набір знань який дозволить розпочати впевнену роботу із доктринальними публікаціями СВ США та прискорити процес їх вивчення.
\end{abstract}

Ключові слова: доктрини, доктринальні публікації, керівні документи СВ США, ієрархія доктрин СВ США, основи доктрин СВ США (ADP, ADRP, FM, ATP, JP, AJP, MTTP, MCDP, MCWP, MCTP, MCIP, NDP, NWP, NTTP, NTRP).

\section{Постановка проблеми}

Збройним Силам України визначено завдання перейти на стандарти НАТО до кінця 2020 року [1, 2]. На виконання цих рішень у Збройних силах України розроблено
Ієрархію доктринальних документів та затверджено План щодо їх опрацювання до кінця 2020 року [3]. Основою для майбутніх доктрин мають стати досвід ведення ООС

\footnotetext{
* Corresponding author: старший викладач кафедри, e-mail: victor.rossiytsev@gmail.com, ORCID: 0000-0001-6176-0108
} 
(АТО) та сучасні стандарти і принципи, прийняті у збройних силах країн - членів НАTO [3]. Загальна кількість військових керівних публікацій які підлягають опрацюванню складає 272 документи, з них 85 у структурних підрозділах Генерального штабу та 187 у видах, окремих родах військ (сил) ЗС України [3].

Разом з тим крім кількості документів які необхідно розробити, запровадженню нової системи доктринального забезпечення заважатимуть декілька факторів, основними 3 яких є:

обмежений час, визначений на розробку доктрин (у ЗС США орієнтовний показник розробки нового доктринального документу складає 18 місяців або 2755 чол./год, проте у ЗСУ на розробку нових доктрин виділено від трьох до дев'яти місяців) [4];

незнання або недостане знання розробниками доктрин іноземної мови та іноземної військової термінології;

відсутність доступу до офіційних джерел документів НАТО (країн членів НАТО) та незнання процедур їх офіційного витребування;

відсутність у ЗС України офіційних аналогів Центрів досконалості які існують у НАТО (країнах-членах НАТО) за напрямками розробки доктрин (одним із основних завдань центрів досконалості крім збору, узагальнення, накопичення і розповсюдження набутого досвіду за напрямком роботи $€$ участь або безпосередня розробка доктринальних документів) [18];

відсутність структурного підрозділу Генерального штабу ЗСУ який би безпосередньо відповідав за створення та розбудову системи доктринального забезпечення ЗСУ за прикладом Директорату загальновійськових доктрин/Combined Arms Doctrine Directorate Центру досконалості керівництва військами/Mission Command Center of Excellence Загальновійськового центру/Combined Arms Center Командування підготовки СВ США/U.S. Army Training and Doctrine Command [4] (наразі запровадження зазначеної функції виконана шляхом додавання слова "доктрин" до назв деяких структурних підрозділів органів військового управління ЗС України та додаткового навантаження на існуючі підрозділи без збільшення штатної чисельності військовослужбовців);

відсутність спеціальної курсової підготовки та планових зборів (конференцій, семінарів) 3 особовим складом залученим до розробки доктрин (яка проводиться у провідних країнах-членах НАТО);

суттєву різницю у підходах до деяких видів воєнних дій між Україною та провідними країнами НАТО (США та Великобританія, на відміну від України, не проводять стабілізаційні дії (операції) на власній території, а лише за їі межами $[5,6]$. Це питання потребує додаткового вивчення та прийняття відповідних рішень. Як результат, можливе введення нового виду воєнних дій Військова підтримка цивільної влади, за прикладом США та Великобританії [5, 7]. Введення нового виду воєнних дій потребуватиме повторного переопрацювання всіх військових керівних публікацій, починаючи 3 Доктрини застосування сил оборони держави).

відсутність посадової особи яка відповідає за систему узгодження та запровадження термінології і умовних знаків що призводить до відсутності офіційного та повноцінного довідника термінів і умовних знаків який би відповідав потребам військовослужбовців та вимогам провідних країн членів НАТО.

Термін розробки нових доктрин спливає до кінця 2020 року. Більшість з них будуть затверджені на момент виходу статті. Разом 3 тим, враховуючи невирішені проблеми системи доктринального забезпечення, можна спрогнозувати неминуче переопрацювання доктрин 2020 року. Вирішити зазначені проблеми можливо врахувавши досвід провідних країн НАТО. В першу чергу це стосується досвіду Сухопутних військ США формалізованого у найбільш розвиненій та відкритій системі доктринального забезпечення світу.

Вирішення всіх проблем не можливе в 
рамках однієї статті. Основна увага дослідження буде спрямована на вирішення проблем з доступом до керівних документів CВ США як провідного виду збройних сил найвпливовішої країни члена НАТО. Також стаття коротко розгляне деякі керівні документи СВ США, положення яких містять потенційне рішення щодо створення дієвої системи доктринального забезпечення. В цілому доступ до керівних документів CB США буде корисним у підготовці майже всіх доктринальних документів ЗС України та вирішення значної кількості наявних проблем.

\section{Аналіз останніх досліджень та публікацій}

Основним джерелом доктринальних публікацій ЗС та СВ США є офіційні репозиторії документів, значна більшість яких розташовані у відкритому доступі в мережі Інтернет. Загальні відомості щодо системи доктринального забезпечення СВ США висвітлені у Доктринальній публікації 1-01 "Основи Доктрин" (ADP 1-01 Doctrine primer) [13]. Найбільш зручним інформаційнодовідковим матеріалом щодо наявних та запланованих доктринальних документів які використовуються У СВ США станом на червень $2020 \in$ Довідник доктринальних документів (Doctrine Smart Book) [21].

3 іноземних фахових періодичних видань слід відмітити професійний журнал СВ США “Військовий огляд" (Military Review), журнал Інституту стратегічних досліджень Коледжу CB США Пенсильванії "Параметри" (Parameters) та військовий незалежний професійний інтернет ресурс “Журнал Локальних конфліктів" (Small Wars Journal). За кордоном, дослідження доктрин 3С США проводили М. Вего, А. Джексон, М. Скуллі, Д. Анкер, Д. Толлефсон.

Особливе місце у вітчизняних дослідженнях доктрин ЗС США слід відвести науковцям Національного університету оборони України імені Івана Черняховського. Дослідженнями системи доктринального забезпечення СВ США займались такі вітчизняні науковці як В. Фролов, Ф. Саганюк, А. Устименко, А. Павліковський. Питання доктрин окремих родів військ СВ США вивчали Ю. Репіло, С. Салкуцан, О. Шевченко, Д. Демидко, М. Адаменко [10] та С. Піскунов, А. Волков, Ю. Галкін, М. Бречка [11]. Особливостями процесу планування СВ США займались М. Гребенюк, С. Салкуцан,
О. Остах, А. Шигида. Одним з найкращих вітчизняних описів доктринальних документів ЗС США є підрозділ 2.4 монографії “Оборонна реформа: системний підхід до оборонного менеджменту" [8]. Також необхідно відзначити роботу 3 основ планування операцій за стандартами НАТО [9] яка розкриває історико-теоретичний контекст та містить один 3 найкращих вітчизняних переліків основних понять i визначень доктрин ЗС США.

Водночас, аналіз вітчизняних робіт показує що деяка інформація щодо доктринального забезпечення СВ США або відсутня, або вже встигла застаріти і потребує уточнення. Зокрема не розкриті види, типи та взаємозв'язок доктрин в системі військових керівних публікацій СВ США, основні етапи розвитку, причини і результати реформування системи доктринального забезпечення 2009-2016 років та відповідно не враховано зміни в ієрархії і змісті доктрин СВ США 2017 - 2019 років.

Також, проблемою більшості вітчизняних досліджень можна зазначити, відсутність посилань на офіційні джерела доктрин 3 С США, використання неофіційних репозиторіїв керівних документів та їх неофіційних перекладів. Як наслідок, це у кращому випадку призводить до роботи із застарілими версіями доктрин. Іншою проблемою роботи 3 керівними документами СВ США, крім необхідного рівня знання військової термінології англійською мовою, $€$ те, що досі значна кількість дослідників не знають про можливість відкритого доступу до більшості керівних документів СВ США і відповідно не користуються цією нагодою. У цілому, не зважаючи на важливість вивчення доктрин CB 
США для приведення ЗС України до стандартів і принципів провідних країн НАТО, на сьогодні відсутні практичні рекомендації щодо порядку роботи із доктринальними документами СВ США.

\section{Постановка завдання}

Метою статті $\epsilon$ з'ясування базових знань про систему доктринального забезпечення СВ США, мінімально необхідних для орієнтування у тисячах керівних публікацій які входять до ії складу та розроблення на основі отриманих знань пропозицій щодо початку роботи із ними.

Мету роботи буде досягнуто з'ясуванням та уточненням:

сутності поняття "доктрина" з точки зору військових фахівців ЗС США та основних видів військових керівних публікацій СВ США;

видів, типів та ієрархії доктринальних документів СВ США та взаємозв'язку між ними;

основних етапів розвитку системи доктринального забезпечення СВ США;

офіційних репозиторіїв та порядку доступу до відкритих доктринальних публікацій які використовуються у СВ США;

основ системи реєстраційних позначень доктринальних документів;

За результатами роботи буде розроблено пропозиції щодо початку роботи із доктринальними документами СВ США.

\section{Виклад основного матеріалу}

1. Сутність поняття “доктрина" з точки зору військових фахівців ЗС США та основні види військових керівних публікацій СВ США

Збройні сили України продовжують адаптацію вітчизняних керівних документів до стандартів провідних країн членів НАТО. Однією із змін $€$ запровадження наказу Генерального штабу ЗС України від 26.12.2018 №460 “Про затвердження Тимчасового порядку оформлення військових публікацій у Збройних Силах України" [12]. Зазначений наказ визначає, що одним із видів документів, що входять до військових публікацій, $\epsilon$ Доктрини. Відповідно зазначеного наказу, доктринальні документи (доктрини) це "документи, які визначають систему офіційних поглядів i положень щодо управління, застосування, підготовки та забезпечення Збройних Сил України". Поняття доктрин запозичено із системи доктринального забезпечення ЗС США, основу якого складає доктринальне забезпечення найбільшого та найстарішого виду збройних сил США Сухопутних військ.

Доктринальна публікація 1-01 “Основи Доктрин" (ADP 1-01 Doctrine primer) [13], Сухопутні війська США виділяють чотири основні типи військових керівних публікацій: Адміністративні настанови і інструкції (Army regulations and pamphlets), Доктрини (Doctrine), Рекомендації (стандарти) підготовки (Training publications) та Технічні керівництва 3 експлуатації (обслуговування, ремонту) озброєння і військової техніки (Technical manuals). У свою чергу, Доктрини які використовуються у СВ США можна класифікувати за видами (об'єднані доктрини, багатонаціональні, міжвидові, видові) та типами військової керівної публікації ієрархії доктрин СВ США (Доктринальні публікації, Польові статути, Технічні прийоми) [13]. Більш детальна інформація щодо решти типів керівних документів СВ США зазначена у [40]. Основна увага цієї статті буде зосереджена на видових доктринальних документах СВ США та ïх типах (ADP, FM, ATP). Також буде коротку характеристику видів доктрин (об'єднані доктрини, багатонаціональні, міжвидові, видові) і взаємозв'язку між ними.

Доктрина (доктринальна) публікація згідно з поглядами фахівців СВ США це вид військової керівної публікації який визначає “фундаментальні принципи на основі яких побудовано тактику, способи виконання завдань, процедури, термінологію та умовні знаки, що використовуються під час застосування СВ США і які $\epsilon$ основою для діяльності військових організаційних структур 
(бойового складу та частин забезпечення) спрямованої на захист національних інтересів" [13]. Доктрини розробляються із завданнями: забезпечити єдність поглядів на ведення збройної боротьби; виробити єдиний понятійний апарат (визначень та професійної лексики); підвищити ефективність ведення бойових дій; визначення та розвиток потрібних рис військовослужбовців та їх командирів (начальників); формулювання завдань та визначення порядку участі СВ США у складі міжвидових та об'єднаних формувань [13].

Історично, термін доктрина, походить від латинського doctrina - "вчення, теорія, система поглядів". Задовго до ЗС США цей термін сторіччями використовувався представниками католицької церкви для позначення текстів святого письма [14]. Як і в церкві, доктрина $€$ письмовим зводом знань і принципів СВ США які накопичені з моменту їх формування і по сьогоднішній час. Сукупність досвіду, знань та принципів СВ США формалізовані в ієрархічній системі доктринальних публікацій. В цілому, таксономія системи доктринального забезпечення СВ США представлена на мал. 1.

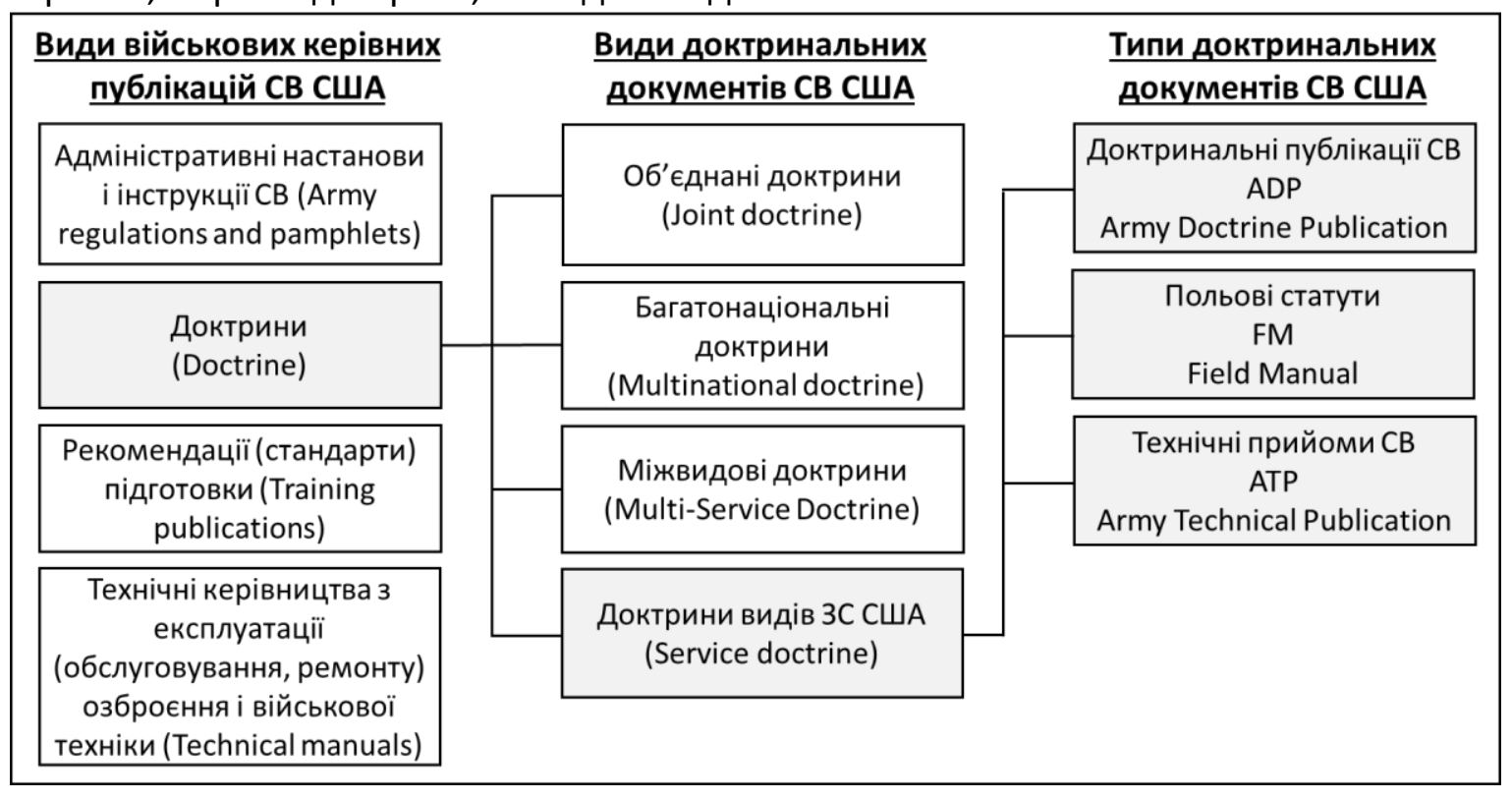

Малюнок 1 - Таксономія системи доктринального забезпечення СВ США Розроблено та перекладено автором за даними [13]

\section{2. Види, типи, ієрархії доктринальних документів СВ США та взаємозв'язок між ними}

Доктрини видів ЗС США існують в загальній системі доктринального забезпечення 3С США. Зазначена система не така чітка і централізована як у зС України і кожний вид ЗС США має власне бачення щодо ії ієрархії та видів документів які до неї входять. 3 точки зору СВ США, до системи доктринального забезпечення ЗС США відноситься чотири види доктрин: об'єднані, багатонаціональні, міжвидові та видові [13]. Найвищий рівень iєрархії займають Об'єднані доктрини (Joint Doctrine). У теорії, доктрини верхніх рівнів завжди ініціюють зміни у доктринах нижнього рівня. Відповідно, під час розробки Видових і Міжвидових керівних документів розробники повинні враховувати вимоги об'єднаних публікацій (Joint Publications). Однак на практиці, начальник штабу виду ЗС США завжди має право ініціювати розробку нової об'єднаної доктрини або внесення змін до існуючих доктрин верхніх рівнів, особливо в частині що стосується сфери його безпосередньої компетенції [13].

Об'єднані доктрини - це сукупність основоположних настанов і принципів якими керуються збройні сили Сполучених Штатів під час скоординованих дій спрямованих на досягнення спільної мети і які можуть включати спеціальну термінологію, технічні прийоми, 
процедури та окремий порядок підготовки, застосування і розміщення військ [22]. На жовтень 2020 у ЗС США використовувалось 77 Об'єднаних доктрин та ще 4 знаходилось у стадії розробки. Відповідальність за розробку та затвердження Об'єднаних доктрин лежить на Голові Об'єднаного комітету начальників штабів ЗС США. Також, Об'єднані доктрини забезпечують загальний контекст для розробки Міжвидових доктрин які будуть розглянуті нижче.

Об'єднані доктрини $€$ відносно новим видом доктринальних документів ЗС США. Вони з'явились лише на початку 90-х років 20 сторіччя і в основному, спрямовані на організацію ефективної міжвидової взаємодії та забезпечення роботи об'єднаних штабів. Історично види ЗС США розвивались незалежно один від одного і мали окремі бюджети які затверджувались Конгресом. Відповідно, кожен вид самостійно розробляє керівні документи які регулюють всі сфери діяльності його військових організаційних структур, за винятком організації міжвидової взаємодії.

В контексті доктринального забезпечення це призводить до того, що види мають як різні ієрархії керівних документів так і власні процедури планування і прийняття рішень (таб. 1). Наприклад СВ США використовують три методики прийняття рішень (Army Design Methodology, Military Decision Making Process, Troop leading Procedures), Військово-морські сили використовують Процес планування BMC (The Navy Planning Process), Морська піхота яка фактично $\epsilon$ одним із родів військ Військово-морських сил використовує Процес планування Морської піхоти (Marine Corps Planning Process), Військово-повітряні сили Процес прийняття рішення об'єднаних повітряних сил (Joint Air Estimate Process) [28]. Як видно з наведених прикладів, уніфікація систем прийняття рішень у ЗС США відсутня навіть між ВМС та одним із їі родів військ Морською піхотою.

Таблиця 1 - Порівняння Ієрархій доктринального забезпечення основних видів ЗС США та їх систем прийняття рішень

\begin{tabular}{|c|c|c|c|c|}
\hline Вид ЗС США & СВ США & ПС США & ВMС США & Мп США \\
\hline 1 рівень доктрин & $\begin{array}{l}\text { ADP } 1 \\
\text { ADP 3-0 }\end{array}$ & $\begin{array}{c}\text { Volume } 1 \text { Basic Doctrine } \\
\text { Volume } 2 \text { Leadership }\end{array}$ & NDP & MCDP \\
\hline 2 рівень доктрин & $\begin{array}{c}\text { ADP, FM } \\
\text { (Решта ADP та } \\
\text { визначені 14 FM) }\end{array}$ & $\begin{array}{c}\text { Operational doctrine } \\
\text { Volume } 3 \text { Command } \\
\text { and Annexes }\end{array}$ & NWP & MCWP \\
\hline 3 рівень доктрин & FM & Tactical doctrine / TTP & NTTP & МСТP \\
\hline 4 рівень доктрин & ATP & - & NTRP & MCRP \\
\hline 5 рівень доктрин & - & - & - & MCIP \\
\hline $\begin{array}{c}\text { Система прийняття } \\
\text { рішень (Керівний } \\
\text { документ) }\end{array}$ & $\begin{array}{c}\text { Design methodology, } \\
\text { MDMP, TLP } \\
\text { (FM 6-0) }\end{array}$ & $\begin{array}{c}\text { Joint Air } \\
\text { Estimate Process } \\
\text { (AFMAN 10-40 V2) }\end{array}$ & $\begin{array}{c}\text { The Navy } \\
\text { Planning Process } \\
\text { (NWP 5-01) }\end{array}$ & $\begin{array}{c}\text { Marine Corps } \\
\text { Planning Process } \\
\text { (MCWP 5-10) }\end{array}$ \\
\hline
\end{tabular}

(Розроблено автором за даними [13, 28-31])

Теж саме відбувається і 3 ієрархією доктринальних документів видів ЗС США. Як вже зазначалось СВ США використовують: Доктринальні публікації (Army Doctrine Publication, ADP), Польові статути (Field Manual, FM) і Технічні прийоми (Army Technical Publication, ATP). Повітряні Сили США: Визначальні доктрини (Том 1 - Основні положення/Volume 1 Basic Doctrine, Toм 2 -
Лідерство/Volume 2 Leadership), Доктрини застосовування оперативного рівня/Operational Doctrine (Том 3 - Управління / Command, Додатки - Annexes) і Доктрини застосування тактичного рівня/Tactical Doctrine (Тактики, технічні прийоми і процедури/Tactics, Techniques, and Procedures) [29]. Корпус Морської піхоти (далі - МП) СШАДоктринальні публікації Морської піхоти 
(Marine Corps Doctrine Publications, MCDP), Бойові статути МП (Marine Corps Warfighting Publications, MCWP), Тактичні публікації МП (Marine Corps Tactical Publications, MCTP), Довідкові публікації МП (Marine Corps Reference Publications, MCRP) та Тимчасові публікації МП (Marine Corps Interim Publications, МСІР) [30]. Військово-морські сили США Доктринальні публікації BMC (NAVY Doctrine Publications, NDP), Бойові статути BMC (NAVY Warfighting Publications, NWP), Тактики, технічні прийоми і процедури BMC (NAVY Tactics, Techniques, and Procedures, NTTP), Тактичні довідкові публікації ВMC (NAVY Tactical Reference Publications, NTRP) [31].

Іншим видом доктрин, дещо схожим за призначенням на Об'єднані доктрини ЗС США $\epsilon$ Багатонаціональні доктрини (Multinational Doctrine). Багатонаціональні доктрини містять узгоджені фундаментальні принципи, на основі яких проводиться скоординоване застосування військ (сил) двох або більше націй спрямоване на досягнення спільної мети [23]. Зазначені доктрини унормовують участь ЗС США у багатонаціональних (коаліційних або союзницьких) операціях та операціях під проводом НАТО, ООН і ОБСЕ. Наразі, СВ США залучаються для участі у складі шістьох таких альянсів і договорів [24]: Організація об'єднаних націй (UN); Північно-атлантичний альянс (NATO); Програма збройних сил США, Великобританії, Австралії, Нової Зеландії (ABCANZ); Договори про оборону та співробітництво із республікою Корея та Японією; Міжамериканський договір про взаємну допомогу; Міжнародні сили сприяння безпеці в Афганістані (ISAF).

Під час участі у багатонаціональних операціях, ЗС США повинні використовувати визначені багатонаціональні доктринальні документи ратифіковані Сполученими Штатами. Прикладами таких доктрин $є$ Угоди стандартизації HATO (NATO STANAGs) або стандарти Програми збройних сил США, Великобританії, Австралії, Нової Зеландії (ABCANZ standard) [23]. У разі використання коаліцією або альянсом багатонаціональних доктрин не ратифікованих США, командири за можливості дотримуються них, але за умови їх

відповідності законодавству США,
міжнародному законодавству i y деяких випадках законодавству країни на території якої проводиться багатонаціональна операція [24]. Основні документи що регламентують використання багатонаціональних доктрин під час застосування СВ США у багатонаціональних операціях $€$ Об'єднана публікація JP 3-16 Багатонаціональні операції [23] та Польовий статут FM 3-16 CB США у Багатонаціональних операціях [24].

В операціях під проводом НАТО, ЗС США зобов'язані слідувати доктринам НАТО [13]. Як зазначає Доктринальна публікація СВ США 1-01 “Основи доктрин" - "НАТО є єдиною організацією яка розробляє справжні багатонаціональні доктрини які у значній мірі заповнюють ту ж саму нішу що й Об'єднані доктрини ЗС США". В той же час слід зауважити, що доктринальні документи ЗС США достатньо гармонізовані із доктринальними документами НАТО. Органи військового управління на яких покладена відповідальність за розробку доктринальних документів, зобов'язані забезпечити належне представництво інтересів ЗС США у робочих групах НАТО із розробки доктрин [25]. Представники США приймають активну участь у цих групах і вживають всіх необхідних заходів спрямованих на врахування інтересів ЗС США. Як приклад можна навести затвердження у 2019 році процесу прийнятя військових рішень тактичного рівня НАТО який $€$ точною копією процесу MDMP який використовують у СВ США [26].

Наступним елементом ієрархії доктрин ЗС США $€$ міжвидові доктрини. Міжвидова доктрина це вид військової спільної міжвидової керівної публікації (multi-Service publication) яка затверджена двома або більше видами ЗС США. Міжвидові доктрини містять принципи, терміни, тактику, технічні прийоми і процедури щодо певного виду військових завдань, порядок виконання якого відповідає вимогами Об'єднаних доктрин [13]. Вони використовуються як звичайні видові доктрини та містять реєстраційні позначення кожного виду ЗС США що їх затвердив. Основними документами які визначають загальний 
спільний контекст для розробки Міжвидових доктрин $€$ Об'єднані доктрини ЗС США.

Станом на вересень 2020 СВ США використовують 41 спільну міжвидову військову публікацію, із них 1 Польовий статут та 40 Технічних прийомів. Відповідальність за розробку Міжвидової доктринальної публікації може бути покладена на будь який вид ЗС США, однак найбільшу кількість 3 існуючих міжвидових публікацій які використовуються у СВ США розробив спеціально створений у 1992 році Об'єднаний Центр застосування Повітряної, Наземної та Морської компоненти (Air Land Sea Application Center). До складу Центру входять представники Сухопутних військ, Повітряних сил, Військово-морських сил та Морської піхоти ЗС США. Головним завданням Центру $€$ вивчення проблемних питань міжвидової взаємосумісності тактичного рівня та розробка відповідних Міжвидових публікацій які вирішують цю проблему [33]. Прикладом такої військової керівної публікації $€$ Спільна міжвидова публікація тактики, технічних прийомів та процедур для проведення Операцій 3 підтримки миру (Multi-service tactics, techniques, and procedures for Peace operations ATP 3-07.31 MCTP 3-03B AFTTP 3-2.40) [27]. Зазначена публікація розроблена Центром для підрозділів та військових частин Сухопутних військ, Повітряних сил та Морської піхоти ЗС США як настанова з планування та проведення операцій з підтримки миру на оперативному та тактичному рівнях. Після затвердження зазначеними видами, їй був присвоєний відповідний реєстраційний номер від кожного виду ЗС США.

Заключним видом доктрин ЗС США є Видові доктрини. Доктрина Виду ЗС США це доктринальний документ який затверджується видом ЗС США і призначений для використання виключно у цьому виді ЗС США. Доктрини видів ЗС США мають свою ієрархію та порядок реєстраційних позначень. У наступних розділах будуть розглянуті ключові етапи розвитку, ієрархія, порядок розробки і уточнення, стан, офіційні репозиторії, система реєстраційних позначень та загальний порядок роботи 3 доктринальними публікаціями СВ США.

\section{3. Основні етапи розвитку системи доктринального забезпечення СВ США}

Сучасна система ієрархії доктринальних документів СВ США бере свій початок із публікації Настанови з порядку та дисципліни військ США Барона фон Стюбена 1779 року (Baron von Steuben's Regulations for the Order and Discipline of the Troops of the United States) [13]. На початок 1900 року, загальна кількість доктринальних публікації СВ США зросла до 40. Основу доктрини того часу складали Настанови з польової служби (Field service regulations) та стройові статути (Drill manuals).

З 1939 по 1999 доктрина СВ США складалась з польових статутів (Field manuals, FM). У 20042009, СВ США використовували Тимчасові польові статути (Field manuals interim, FMI) разом із Тактиками, техніками і процедурами CB США (Army tactics, techniques, and procedures, ATTP). Тимчасові польові статути це доктринальні документи СВ США з терміном дії не більше двох років та які прийняті за прискореною процедурою з метою вирішення невідкладних проблем які виникли у військах [39]. Необхідність запровадження Тимчасових польових статутів була викликана початком військових операцій у Іраку та Афганістані після терористичних атак 11 вересня 2001 року. Як результат, доктринальна база СВ США зразку 2009 року включала більше 500 публікацій [13].

Незважаючи на якісне наповнення доктринальної бази 2009 року, така кількість військових публікації значно ускладнювала пошук необхідної інформації. Системі доктринального забезпечення бракувало чіткої ієрархії яка би дозволила класифікувати та визначати пріоритетність інформації. Керівництво СВ США звернуло увагу на те, що однією з причин слабких знань доктрин особовим складом СВ США є кількість та обсяг доктринальних документів [15]. Значна кількість військовослужбовців не розуміли які 3 500 польових статутів $€$ обов'язковим до вивчення, а які призначені лише для вузького кола фахівців. Як наслідок, 2009 рік став початком роботи над прототипом існуючої системи доктринальних документів під назвою “Доктрина 2015", яка призвела до кардинальної реформи доктринального 
забезпечення СВ США.

Безпосереднє завдання щодо розробки проекту “Доктрини 2015” було покладено на Загальновійськовий Центр СВ США (Combined Arms Centre). Проект “Доктрини 2015” мав забезпечити зручний пошук потрібної інформації та зменшити кількість і обсяги доктринальних документів [15]. “Доктрина 2015" передбачала чотири рівні доктринальних документів (Доктринальні публікації, Доктринальні уточнюючі публікації, Польові статути, Технічні прийоми). Всього, передбачалось створення 15 Доктринальних публікацій СВ США (Army Doctrine Publication, ADP) обсягом до 10 сторінок, 15 Доктринальних уточнюючих публікацій (Army Doctrine Reference Publication, ADRP) обсягом до 100 сторінок, 50 Польових статутів (Field Manual, FM) обсягом до 200 сторінок та Технічні прийоми СВ США (Army Techniques Publication, ATP), без регламентації їх кількості та розміру $[10,16]$. У такому вигляді Іерархія доктринальних публікацій проекту “Доктрини 2015” проіснувала до 2019 року (мал. 2).

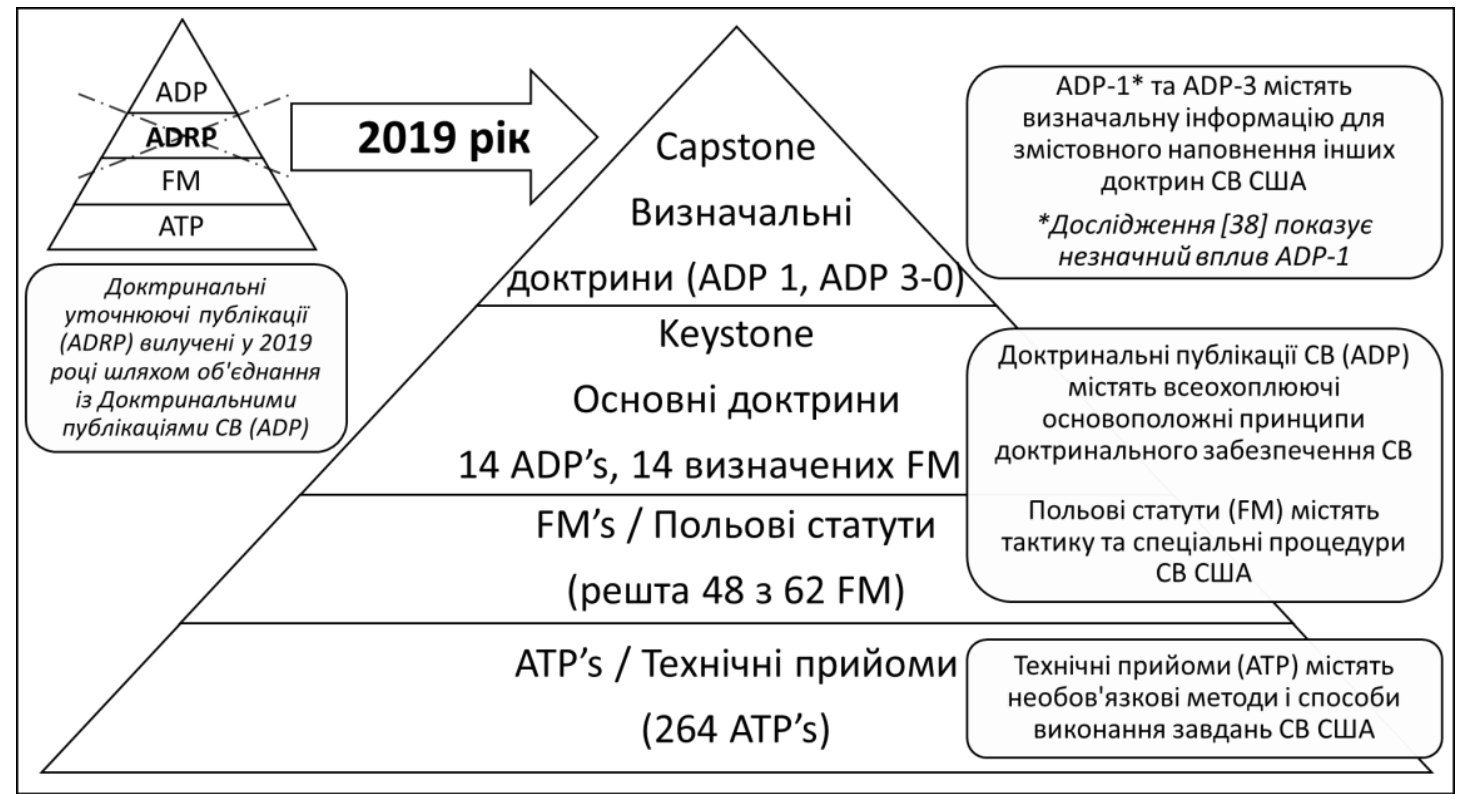

Малюнок 2 - Відображення нечіткого числа

Доктринальні публікації CB CША (ADP) планувались як документи вищого рівня ієрархії доктринального забезпечення. Вони визначали фундаментальні принципи застосування СВ США. Проектом “Доктрина 2015" передбачалось дві категорії Доктринальних публікацій СВ США визначальні (Capstone doctrine) та основні (Keystone) [16, 21]. До складу входили дві доктринальні публікації - Сухопутні війська (ADP 1 The Army) та Об'єднані наземні операції (ADP 3-0 Unified Land Operations). До основних відносились тринадцять публікацій (ADP 1-02 Довідник визначень та умовних знаків, ADP 2-0 Розвідка, ADP 3-90 Наступальні та оборонні операції, ADP 3-07 Стабілізаційні операції, ADP 3-05 Спеціальні операції, ADP 3-09 Вогневе ураження, ADP 3-28 Підтримка цивільних органів, ADP 3-37, Захист військ, ADP 4-0 Забезпечення, ADP 5-0 Ведення операцій, ADP 6-0 Бойове управління, ADP 6-22 Керівництво військами, ADP 7-0 Підготовка) $[13,16]$. Кожна Доктринальна публікація CB (ADP) доповнювалась Доктринальною уточнюючою публікацією (ADRP), яка у свою чергу деталізувала принципи визначені У Доктринальних публікаціях СВ США (ADP) [13].

Наступними в ієрархії доктрин йшли Польові статути. Метою Польових статутів (Field Manual, FM) $€$ розкриття тактик (підготовка, ведення бойових дій і упорядковане розміщення військ під час спільних дій) [17] та процедур (стандарти та покрокові інструкції які деталізують порядок виконання завдань) [17] 
визначених у Доктринальних публікаціях ADP або Доктринальних уточнюючих публікаціях ADRP [13]. Положення польових статутів вимагають суворого дотримання визначених ними тактик і процедур та є обов'язковими до виконання для особового складу і військових організаційних структур СВ США. Всі польові статути поділені на 6 основних груп: Вирішальні дії (Decisive action) 4 статути, Функції бойового застосування (Warfighting Functions) 9 статутів, Роди військ та служб (Branches) 17 статутів, Типи операцій (Types of operations/Activities) 13 статутів, Інші ешелони (Other Echelons) 3 статути та Довідкові публікації (Reference publications) 4 статути [16]. Наразі з 62 польових статутів, 14 відносяться до основних (Keystone) доктрин (FM 1-0, 2-0, 3-0, 4-0, 5-0, 6-0, 7-0, 3-01, 3-04, 305, 3-09, 3-94, 6-02, 6-27) (мал. 2)[21].

Завершували перелік елементів Ієрархії Доктрин СВ США Технічні прийоми (Army Techniques Publication, ATP). Метою видання "Технічних прийомів" $є$ доведення способів та методів виконання завдань які не $\epsilon$ обов'язковими і використовуються на рішення відповідного командира (начальника) [13]. Особливістю зазначеної публікації $€$ наявність електронної версії “Технічних прийомів" яка розміщена на сторінці інформаційного ресурсу 3С США milWiki яка побудована за принципом вільної онлайн-енциклопедії "Вікіпедія". Розміщення зазначеної доктринальної публікації надає можливість кожному військовослужбовцю СВ США взяти участь у підготовці проектів "Технічних прийомів" та пропонувати обгрунтовані зміни до них за допомогою комп'ютера або смартфона під'єднаного до мережі інтернету [4].

Організатором розробки доктрин у СВ США $\epsilon$ Директорат загальновійськових доктрин (Combined Arms Doctrine Directorate) Центру досконалості керівництва військами (Mission Command Center of Excellence) Загальновійськового центру (Combined Arms Center) Командування підготовки СВ США (U.S. Army Training and Doctrine Command) [4]. Директорат загальновійськових доктрин відповідає за організацію та координацію розробки та видання: доктрин СВ США та визначених об'єднаних, багатонаціональних та міжвидових доктрин ЗС США. Безпосередніми розробниками доктрин $є$ військові організаційні структури призначені відповідальними за розвиток відповідних функцій бойового застосування (логістика, розвідка, управління військами, тощо). Перелік відповідальних за розвиток функцій бойового застосування визначається Адміністративною настановою 5-22 Організація та закріплення відповідальності за розвиток СВ США (Army Regulation 5-22 Management The Army Force Modernization Proponent System) [18]. При чому безпосередня відповідальність за розвиток зазначених напрямків покладається не лише на органи військового управління, а й на відповідні навчальні заклади (навчальні центри, школи підготовки) і наукові (навчально-наукові) установи (центри досконалості). Затвердження основних Доктринальних публікації СВ США (ADP 1 Сухопутні війська, Об'єднані наземні операції ADP 3-0, ADP 6-22 Керівництво військами та ADP 7-0 Підготовка) покладається на начальника штабу СВ США (найвища військова посадова особа СВ США) [16]. Решту Доктринальних публікацій (ADP, ADRP, ATP, FM) затверджує керівник Загальновійськового центру СВ США (US Army Combined Arms Center) [16].

Уточнення доктринальних публікацій здійснюється за потреби. Строки дії доктринальних публікацій різні. Деякі оновлюються частіше, ніж інші, однак майже всі підлягають уточненню протягом терміну їх дії. Як приклад, можна навести доктринальну публікацію СВ США “Операції”, внесення суттєвих змін до якої зазвичай призводить до перевидання і уточнення інших доктрин. На вересень 2020 року діє 22-га редакція “Операцій". Починаючи з 1905 року, в середньому, їі уточнювали кожні п'ять років. При цьому п'ять раз строк дії редакцій тривав менше року, а найдовший час між виданнями становив шістнадцять років (1923-1939) [13].

Причинами перевидання доктрин $€$ зміни у безпековому середовищі, способах виконання завдань, зміни у організаційно-штатних структурах військових організаційних структур та постановка на озброєння новітніх зразків озброєння і військової техніки. Як приклад, у 
2017 році, СВ США переорієнтувались 3 проведення протиповстанських (стабілізаційних) операцій на підготовку до повномасштабних бойових дій. Однією 3 причин переорієнтації та джерелом відповідних змін стали агресія Росії та подальший досвід залучення ЗСУкраїни до АТО на сході України [19].

У контексті структури доктрини СВ США, черговий етап переопрацювання доктринальних документів призвів до вилучення $з$ “Доктрини 2015" серії Доктринальних уточнюючих публікацій (ADRP) шляхом їх об'єднання у 2019 році 3 Доктринальними публікаціями СВ (мал.2). В результаті проведених змін станом на жовтень 2020 до системи доктринального забезпечення СВ США входять 342 документа, 3 них: 16 доктринальних публікацій (у 2019 році введено додаткову Доктринальну публікацію ADP 1-01 “Основи Доктрин”), 62 Польових статути та 264 Технічні прийоми СВ США. При цьому, досі залишається чинними Доктринальна уточнююча публікація Універсальний перелік завдань СВ США (ADRP 1-03 The Army universal task list) та Тактика, технічні прийоми та процедури дій загальновійськових підрозділів СВ США в умовах щільної міської забудови (ATTP 3-06.11, Army Tactics, techniques and procedures, Combined arms operations in urban terrain). Зазначені типи доктринальних публікацій залишились з попередніх Ієрархій доктринального забезпечення проте входять до переліку чинних керівних документів СВ США.

\section{4. Основи системи реєстраційних} позначень доктринальних документів СВ США

3 метою полегшення пошуку необхідної інформації у доктринальних публікаціях СВ США, кожної з них присвоюється відповідне реєстраційне позначення [20]. Повноваження щодо реєстрації доктринальних документів та призначення їм реєстраційних позначень покладається на Командування підготовки CB США. Позначення публікацій складається 3 літерної та цифрових частин. Літерна частина складається з абревіатури типу доктринальної публікації (ADP, FM, ATP). До складу цифрової частини входять три групи цифрових кодів які розділяються дефісом та комою, наприклад FM 3-13.4.

Перша група цифрових кодів визначає функціональну групу публікацій та може містити лише одну цифру. До номерів функціональних груп доктринальних документів СВ США відносяться: 1-Персонал (Personnel), 2-Розвідка (Intelligence), 3Операції (Operations), 4-Забезпечення (Sustainment), 5-Планування та ведення операцій (Operations Process), 6-Керівництво військами (Mission Command), 7-Підготовка (Warfighter Support). Розподіл на функціональні категорії, у цілому, здійснюється 3 урахуванням функціонального призначення відповідних секції штабу.

Друга група цифрового коду відокремлюється від першої дефісом та може містити одну або дві цифри які відповідають одній з підгруп функціональної групи. Всього до складу семи функціональних груп входить 77 підгруп. Найбільшою з функціональних груп $€$ функціональна група №3 - Операції (Operations), до складу якої ввійшли 45 підгруп. Найменшою $€$ функціональна група №5 Планування та ведення операцій (Operations Process) до якої входить одна підгрупа. Повний перелік підгруп функціональних груп визначено у таблиці 8-2 Настанови 3 видавничої діяльності СВ США [20].

За допомогою третьої групи цифрового коду позначають публікації які розкривають або доповнюють документи підгрупи функціональної групи. Для відокремлення третьої групи цифрового коду від другої використовують крапку. Третя група як і друга складається з однієї або двох цифр. Як правило, третя група цифрового коду не використовується для позначення Доктринальних публікацій (ADP) та Польових статутів (FM).

В цілому методика нумерації забезпечує зручний пошук та навігацію у системі доктринальних публікацій. Однак варто відзначити що у системі позначення документів існують виключення та досі залишаються публікації які порушують порядок нумерації затверджений Настановою 3 видавничої діяльності СВ США. До них можна віднести такі 
доктринальні публікації як:

Сухопутні війська (ADP 1 The Army), цифрове позначення якої складається з однієї цифри і яка не відноситься до функціональної групи №1-Персонал (Personnel) та Основи доктрин (ADP 1-01 Doctrine primer) і Довідник визначень і умовних знаків (ADP 1-02 Terms and military symbols) які підтримують публікацію Сухопутні війська (ADP 1 The Army) і також не відносяться до функціональної групи Персонал;

Доктринальна уточнююча публікація Універсальний перелік завдань СB США (ADRP 1-03 The Army Universal Task List) та Тактика, технічні прийоми та процедури дій загальновійськових підрозділів СВ США в умовах щільної міської забудови (АТТР 3-06.11, Army Tactics, techniques and procedures, Combined arms operations in urban terrain) які залишилась 3 попередньої системи доктринальних публікацій але залишаються чинними;

Польовий статут Дії підрозділів позначення сил противника (FM 7-100.1 Opposing force operations), позначення другої цифрової підгрупи якого складається 3 трьох цифр замість однієї або двох;

Польові статути Оборона і Наступ том 1 (FM 3-90-1 Offense and defense volume 1) та Розвідка, безпека і тактичні завдання оперативного та бойового забезпечення том 2 (FM 3-90-2 Reconnaissance, security, and tactical enabling tasks volume 2) для позначення яких використовується другий дефіс та розподіл на томи, та деякі інші керівні публікації.

5. Офіційні репозиторії та порядок доступу до відкритих доктринальних публікацій які використовуються у СВ США

Як вже зазначалось вище, переважна кількість військових керівних публікацій СВ США розташовані у відкритому доступі мережі Інтернет. Однак аналіз списків використаної літератури наукових статей, які досліджували доктрини СВ США і були опубліковані українською мовою до 2020 року показав, що більшість з них не містили документи завантажені 3 офіційних репозиторіїв. Основними причинами відсутності посилань на офіційні джерела $є$ блокування сайтами СВ США доступу до офіційних репозиторіїв 3

\section{Українських}

IP адрес до 2020 року та недостатні знання англійської мови які спонукали дослідників використовувати неофіційні переклади старих публікацій. Як наслідок, зазначені дослідження не використовували офіційні версії чинних доктринальних документів, що $є$ суттєвою проблемою, враховуючи періодичність та масштаб оновлення керівних документів СВ США у останні роки.

Інструкція з порядку видавництва доктрин Командування підготовки та доктрин СВ ЗС США (TRADOC Regulation 25-36) визначає перелік офіційних репозиторіїв доктринальних публікацій. Наразі зазначена Інструкція перепрацьовується і вказана адреса репозиторію не працює. Наступне місце у якому зазначена адреса офіційного репозиторію є друга сторінка будь якої діючої доктринальної публікації СВ США останніх років. Однак зазначена адреса перенаправляє на сайт вхід на який потребує персональної картки доступу військовослужбовця ЗС США.

Основний офіційний репозиторій який доступний з України починаючи з 2020 року і не потребує використання віртуальних приватних мереж $з$ американськими IР-адресами або картки доступу військовослужбовця $\epsilon$ офіційний сайт Директорату Видавничої діяльності СВ США https://armypubs.army.mil/. Доступ до доктринальних документів на зазначеному сайті можливо отримати якщо перейти за посиланням “Publications", за яким буде розкритий випадаючий список який розкриє перелік керівних публікацій СВ США. Наступний крок, у випадаючому списку обрати розділ “Doctrine and Training", який розкриє перелік типів доктринальних публікацій. Після вибору потрібного типу публікації (ADP, FM, ATP, тощо) буде розкрито перелік всіх чинних версій зазначеного типу документу, більшість яких доступно для завантажування.

Більша частина доктринальних документів, які містяться на сайті Директорату Видавничої діяльності СВ США мають гриф А “не обмежене розповсюдження"

(A; APPROVED FOR PUBLIC RELEASE; DISTRIBUTION IS UNLIMITED). До публікацій CB США $з$ необмеженим доступом станом на 
вересень 2020 відносяться $100 \%$ Доктринальних публікацій CB CША (ADP), 52 з 62 Польових статутів та переважна кількість 3 264 Технічних прийомів. Решта публікацій потребують наявності персональної картки доступу військовослужбовця ЗС США.

Основні типи інформації що закриті від загального розповсюдження $є$ деякі публікації з розвідки, спеціальних операцій, інформаційних операцій, протиракетної оборони, поводження з військовополоненими, тощо. Однак варто зауважити що більшість таких обмежень доступу не потребують від військовослужбовця СВ США персонального отримання документу під особистий підпис із записом до відповідних реєстрів або зберігання його у металевій чарунці із подальшим обов'язковим поверненням його до органу, який його видав. Робота з ним потребує лише картки доступу, яка також $\epsilon$ посвідченням військовослужбовця, та доступу до мережі Інтернет.

Доступ до Міжвидових публікацій які використовуються У СВ США можливо отримати у розділі Технічних прийомів (АТP Army Techniques Publicaions), здійснивши текстовий пошук по сторінці за словом Міжвидові “MULTI-SERVICE”. Однак переважна більшість Міжвидових публікацій не доступна з сайту СВ США, основною причиною чого $є$ різні політики доступу до інформації у різних видах ЗС США. Разом з тим, доступ до деяких відкритих але недоступних публікацій зі сторінки СВ США, можливо отримати зі сторінок інших видів (Повітряних сил, Морської піхоти, тощо).

Основним місцем доступу до Об'єднаних доктрин $€$ сайт Електронної бібліотеки Об'єднаного комітету начальників штабів 3С США. Доступ до бібліотеки можливий за адресою https://www.jcs.mil/Doctrine/. Усі наявні у бібліотеці Об'єднані доктрини відносяться до відкритої інформації. Закрита інформація в Об'єднаних доктринах може заходитись у деяких додатках до доктрин. Об'єднані доктрини кінця 90-х і початку 2000 років містили таємні додатки до доктрин за напрямком Розвідки, Планування вогневого ураження і Пошуково-рятувальних заходів [34].
Однак, на час написання статті, автору не вдалось знайти згадування щодо наявності таємних додатків у чинних версіях Об'єднаних доктрин.

Офіційний доступ до відкритих стандартів НАТО які використовуються як Багатонаціональні доктрини у СВ США значно складніший і часозатратний ніж доступ до звичайних національних доктринальних документів СВ США. Основною проблемою доступу до доктринальних документів НАТО $€$ вимоги НАТО щодо поводження 3 документами “Знати тільки те що потрібно" (Need to know). Сутність цього принципу полягає у тому щоб за допомогою спеціальної інформаційної системи надавати доступ до конкретного документу безпосередньо тим особам, які дійсно ії̈ потребують. Застосування зазначеного принципу розповсюджується не тільки на Інформацію з обмеженим доступом, а й на документи з грифом "Не таємно" (UNCLASSIFIED), до яких відноситься більшість доктринальних документів НАТО [36].

Для отримання стандартів НАТО у ЗС України передбачена спеціальна процедура. Пунктом 4 Розділу 14 наказу Міністерства Оборони України від 24.02.2020 №56 “Про питання військової стандартизації” визначений спеціальний порядок замовлення та отримання міжнародних військових стандартів [35]. Відповідно зазначеного порядку, посадова особа яка потребує доступу до певного стандарту НАТО, опрацьовує запит до органу військової стандартизації ЗС України за формою і прикладами наведеними у додатках до наказу. Орган військової стандартизації, у свою чергу, організовує їх витребування та надсилає встановленим порядком до організації яка їх замовила. Робота із Стандартами НАТО отриманими у відповідності до вищезазначеного порядку - єдиний законний спосіб роботи із доктринальними документами НАТО у Збройних Силах України.

Іншим і простішим варіантом доступу до деяких доктрин НАТО $€$ використання сайту Збройних Сил Великобританії. Пошук та доступ до таких документів можливий за посиланням https://www.gov.uk/government/collections/alli ed-joint-publication-ajp. Частина стандартів на 
зазначеному сайті викладені без змін, а деякі адоптовані 3 урахуванням потреб 3 З Великобританії. Зміст адаптованих документів не змінюється а дещо переформовується для спрощення роботи із ними. Також такі документи можуть доповнюватись національними застереженнями і прикладами застосування цих стандартів. Всі національні доповнення до таких документів обов'язково виділяються. В цілому, якість оформлення адаптованих документі набагато краще ніж у оригінальних документів НАТО. Прикладом такого документу є Об'єднана союзницька доктрина 3 оперативного планування із примітками 3С Великобританії (AJP-5 Allied Joint Doctrine for the planning of operations. Edition $A$ Version 2 with UK national elements) [37].

6. Пропозиції щодо організації початку роботи із доктринальними документами які використовуються у СВ США

Основними вимогами щодо організації роботи із керівними документами СВ США, крім знання англійської мови, $€$ наявність персонального комп'ютера із доступом до мережі інтернет, програмного забезпечення для роботи із PDF-файлами та знання офіційних репозиторіїв відповідних документів. Починаючи із 2012 року "Електронні версії документів є основним способом розповсюдження військових керівних публікацій СВ США" [40]. Наявність друкованої версії можлива, але це скоріше виняток, а не правило [40].

Під час вибору програмного забезпечення для роботи із PDF-файлами бажано звернути увагу на наявність такої функції як одночасний текстовий пошук по декількох документах які розташовані у одній папці. Прикладом такої програми $€$ "PDF-XChange Viewer". Це безкоштовна програма, яка може працювати на старих комп'ютерах і яку можна завантажити за посиланням https://www.tracker-software.com/product/pdfxchange-viewer. Після завантаження та встановлення програмного забезпечення, необхідно створити папку та завантажити із офіційних репозиторіїв п'ять документів, ознайомлення з якими полегшить подальшу роботу та прискорить подальший пошук необхідних публікацій. Посилання на нижче перераховані документи містяться у Списку використаних джерел.

Перший документ це Основи доктрин [13], який містить розгорнуту інформацію представлену у цій статті. Наступні два документи, це переліки термінів FM 1-02.01 [17] та умовних знаків ADP 1-02 [41], які використовуються у доктринальних документах СВ США. Кожен термін або умовний знак, який зазначений у переліках, крім визначення містить посилання на конкретну доктринальну публікацію, яка його запроваджує. Крім того, кожна доктринальна публікація містить внутрішній словник термінів та абревіатур, розділ Індексу сторінок (Index) всіх термінів які використовуються у цій доктрині та перехресні посилання на інші документи які започаткували використання ці термінів та знаків. Якість переліків термінів та умовних знаків забезпечується посадовою особою у Директораті розробки доктрин яка безпосередньо відповідає за цей напрямок роботи (Термінолог СВ США/Army Terminologist) та наявністю відповідних керівних документів і процесів, які регламентують порядок їі роботи і гарантують своєчасне уточнення термінології.

Разом з тим, слід зауважити, що перелік термінів CB США FM 1-02.01 [17] призначений для використання у доктринах СВ США. Він не містить термінологію інших видів 3С США або окремих термінів Об'єднаних доктрин. Для пошуку такої термінології може знадобитись Словник термінів Міністерства оборони США (DOD Dictionary of Military and Associated Terms). Він доступний для завантаження на сайті Електронної бібліотеки Об'єднаного комітету начальників штабів 3С США за посиланням https://www.jcs.mil/Doctrine/DODTerminology-Program/.

Четвертий документ це Довідник доктринальних публікацій СВ США [21]. Довідник не є доктринальним документом, але використовується як допоміжна публікація, яка містить переліки всіх основних доктринальних документів станом на червень 2020. Крім цього там зазначено коротку інформацію про них та Схеми ієрархій доктринальних публікацій за функціями бойового застосування починаючи 
від об'єднаних доктрин (Joint Publications) i закінчуючи відповідними Доктринальними публікаціями (ADP), Польовими статутами (FM) та Технічними прийомами СВ США (АТP). Використання зазначених схем дозволяє швидко скласти переліки необхідних документів за потрібним напрямком роботи. Більш точні переліки можливо знайти у Розділу посилання (References), який знаходиться у кінці кожного доктринального документу. Однак розділ посилання може не враховувати документи які вийшли після затвердження відповідної доктрини.

Останній документ, без розуміння якого не варто починати роботу, це Доктринальна публікація ADP 3-0 Операції [5]. ADP 3-0 є визначальною доктриною СВ США. Зазначена доктрина визначає як Сухопутні війська США та їх підрозділи організовують та ведуть бойові дії у всіх видах операцій багатонаціональних об'єднаних сил. Також, документ містить перелік всіх основних понять та концепцій, які лежать в основі доктринального забезпечення СВ США. Розуміння доктринальних публікацій CB США не можливе без ознайомлення із Доктринальною публікацією ADP 3-0 Операції.
В цілому, завантаження доктрин із офіційних репозиторіїв та роботу із ними можна починати після ознайомлення із перерахованими документами і основами доктринального забезпечення СВ США, викладеними у цій статті. Використання рекомендованого програмного забезпечення дозволить легкий та швидкий текстовий пошук у як відкритому документі так і інших документах які знаходяться у спільній із ним папці. Переліки необхідних документів можна складати за допомогою Довідника [21] та розділу Посилання (References) розташованого у кінці доктринальних публікацій. Основні поняття та концепції роз' яснюються у ADP 3-0 Операції [5], а кожний незнайомий термін і абревіатура знаходяться у переліках термінів [17] та умовних знаків [41]. Більш детальну інформацію про потрібний термін легко знайти за посиланням на відповідний керівний документ який вводить його у дію, а точне місце знаходження терміну у доктринальній публікації можна знайти за текстовим пошуком або у Розділі (Index) відповідного доктринального документа.

\section{Висновки}

За результатами проведеного дослідження можна стверджувати, що робота із системою керівних документів СВ США вимагає певного набору базових знань. Запровадження стандартів провідних країн світу у діяльність Збройних Сил України не можливе без вивчення доктринального забезпечення відповідних країн. Інформація наведена у статті дозволить успішно орієнтуватись та впевнено розпочати роботу із керівними документами СВ США.

3 огляду на наведене, існує потреба у схожих дослідженнях систем доктринального забезпечення інших провідних країн НАТО
(Великобританія, Франція, тощо). Також, необхідно зосередити увагу на принципових відмінностях між доктринальним забезпеченням 3С України та провідних країн світу (різниця між підходами до стабілізаційних дій, військова підтримка цивільної влади як окремий вид дій, концепція одночасного проведення оборони, наступу та стабілізаційних дій або військової підтримки цивільної влади). Зазначені дослідження прискорять вивчення необхідних стандартів та дозволить організувати їх своєчасне впровадження у діяльність ЗС України та інших складових сил оборони.

\section{Список використаних джерел}

1. Закон України “Про національну безпеку України" URL: http://zakon.rada.gov.ua/laws/ show/2469-19?lang=en (дата звернення: 23.05.2020).
2. Стратегічний оборонний бюлетень України: Указ Президента України від 06.06.2016 № 240 Про рішення РНБО України від 20 травня 2016 року “Про Стратегічний оборонний 
бюлетень України" // Офіційне інтернетпредставництво Президента України. URL: http://www.president.gov.ua/documents/240 2016-20137 (дата звернення 23.05.2020).

3. Про затвердження Тимчасового порядку оформлення військових публікацій у Збройних Силах України: наказ Генерального штабу Збройних Сил України від 26.12.2018 №460, особистий архів.

4. TRADOC Regulation 25-36, The TRADOC Doctrine Publication Program, United States Army Training and Doctrine Command Fort Eustis, VA, 21 May, 2014, 82 c. URL : https://adminpubs.tradoc.army.mil/regulation s/TR25-36.pdf (дата звернення 02.06.2020).

5. Army Doctrine Publication 3-0, Operations, Headquarters Department of the Army Washington, DC, July 2019, 102 c. URL : https://armypubs.army.mil/epubs/DR_pubs/D R_a/pdf/ web/ ARN18010_ADP\%2030\%20FINAL\%20WEB.pdf (дата звернення 02.06.2020).

6. Joint Doctrine Publication 05. Shaping a Stable World: the Military Contribution. The Development, Concepts and Doctrine Centre Ministry of Defence Shrivenham SWINDON, Wiltshire, UK, March 2016, 102 c. URL : https://assets.publishing.service.gov.uk/gover nment/uploads/system/uploads/attachment _data/file/516849/20160302-Stable_world_ JDP_05.pdf (дата звернення 02.06.2020).

7. Joint Doctrine Publication 02. UK Operations: the Defence Contribution to Resilience and Security. The Development, Concepts and Doctrine Centre Ministry of Defence Shrivenham SWINDON, Wiltshire, UK, February 2017, 124 c. https://assets.publishing.service. gov.uk/government/uploads/system/uploads/ attachment_data/file/591639/20170207_JDP

02_Resilience_web.pdf (дата звернення 02.06.2020).

8. Оборонна реформа: системний підхід до оборонного менеджменту: монографія / А. Павліковський, В. Фролов, Ф. Саганюк та ін.; за заг. ред. д. військ. Н. А. Сиротенка. К.: НУOУ, 2020. 274 c.

9. Основи планування операцій за стандартами НАТО : навч. посіб. / [М. Гребенюк, С.
Салкуцан, Ю. Остах, А. Шигида]. - Київ: НУОУ ім. Івана Черняховського, 2015. - 120 с.

10. Погляди провідних фахівців НАТО на вогневу підтримку з закритих вогневих позицій: монографія / [Ю. Є. Репіло, С. М. Салкуцан, О. М. Шевченко та ін.]. - К. : НУОУ ім. Івана Черняховського, 2018. - 196 с.

11. Аналіз основних положень статуту бригади військ ППО Сухопутних військ збройних сил США FM 3-01.7(3-01.11) / С.М. Піскунов, А.Ф. Волков, Ю.О. Галкін, М.М. Бречка // Збірник наукових праць Харківського начіонального університету Повітряних Сил. 2019. № 4(62). C. 68-73., DOI: 10.30748/ zhups.2019.62.09.

12. Про організацію розробки доктринальних документів Збройних Сил України: Директива Генерального штабу Збройних Сил України від 13.03.2020 №Д-6., особистий архів.

13. Army Doctrinal Publication 1-01. Doctrine primer. Headquarters Department of the Army Washington, DC, July 2019, 44 c. URL : https://armypubs.army.mil/epubs/DR_pubs/D R_a/pdf/web/ARN18138_ADP\%201-01\%20 FINAL\%20WEB.pdf (дата звернення 02.06.2020).

14. Jackson A. Doctrine, Strategy and Military Culture: Military-Strategic Doctrine Development in Australia, Canada and New Zealand, 1987-2007: Ottawa: Canadian Department of National Defense, 2013, 208 c.

15. Army Doctrine Publication 3-0 An Opportunity to Meet the Challenges of the Future / Ancker C., Scully M. // Military Review / 2013. - №1 c. 38-42. URL: http://cgsc.cdmhost.com/ cdm/ref/collection/p124201coll1/id/1191 (дата звернення 02.06.2020).

16. Doctrine 2015 Information Briefing, United States Army Combined Arms Center. US Army Combined Arms Center (USACAC) Repository : веб-сайт. URL: http://cgsc.contentdm.oclc. org/cdm/singleitem/collection/p16040coll2/id /0 (дата звернення 01.09.2020).

17. Field manual 1-02.01 Operational terms. Headquarters Department of the Army Washington, DC, November 2019, 160 c. URL : https://armypubs.army.mil/epubs/DR_pubs/D 
R_a/ pdf/web/ARN19780_FM\%201-02×1\%20-

\%2OFINAL \%20WEB.pdf (дата звернення 01.09.2020).

18. Army Regulation 5-22 Management The Army Force Modernization Proponent System. Headquarters Department of the Army Washington, DC, 20 October 2015, 19 c. [Електронний ресурс]. - Режим доступу: URL: https://armypubs.army.mil/epubs/DR_ pubs /DR_a/ pdf/web/r5_22.pdf (дата звернення 02.09.2020).

19. Field Manual 3-0. Operations. Headquarters Department of the Army Washington, DC, 6 October, 2017, 363 c. URL : https://armypubs.us.army.mil/doctrine/fm30.pdf. (дата звернення 02.09.2020).

20. Department of the Army Pamphlet 25-40 Army Publishing Program Procedures Headquarters Department of the Army Washington, DC, 13 June 2018, 198 c. URL : https://armypubs.army.mil/epubs/DR_pubs/ DR_a/pdf/web/ARN11758_P25_40_Admin_Fi nal.pdf (дата звернення 02.09.2020).

21. Doctrine Smart book, Combined Arms Doctrine Directorate, United States Army Combined Arms Center Fort Leavenworth, KS, June 2020, 120 c. URL : https://caccapl. blob.core.usgovcloudapi.net/web/repository/ pdf-files/doctrine-smartbook.pdf (дата звернення 02.09.2020).

22. Joint Publication 1, Doctrine for the Armed Forces of the United States, Department of Defence USA, 25 March 2003. URL : https://www.jcs.mil/Portals/36/Documents/ Doctrine/pubs/jp1_ch1.pdf (дата звернення 03.09.2020).

23. Joint Publication 3-16, Multinational Operations, Department of Defence USA, 1 March 2019. URL : https://www.jcs.mil/ Portals/36/Documents/Doctrine/pubs/jp3_16. pdf (дата звернення 04.09.2020).

24. Field Manual 3-16. The Army in Multinational Operations, Headquarters Department of the Army Washington, DC, 8 April, 2014, 168 c. URL: https://armypubs.army.mil/epubs /DR_ pubs/DR_a/pdf/web/fm3_16.pdf. (дата звернення 04.09.2020).

25. CJCSM 5120.01A, Chairman of the Joint Chiefs of Staff Manual, Joint doctrine development process, Joint Staff Washington, DC, 29 December 2014, 131 c. URL : https://www.jcs. mil/Portals/36/Documents/Doctrine/pubs/cjc sm5120_01a.pdf (дата звернення 04.09.2020).

26. APP-28, Allied Procedural Publication, Tactical planning for Land Forces. Edition A, Version 1, NATO Standard, NATO Standardization Office, NATO, 102 c., November 2019

27. Multi-service tactics, techniques, and procedures for Peace operations ATP 3-07.31 MCTP 3-03B AFTTP 3-2.40, Air Land Sea Application (ALSA) Center, 2 May 2019, 132 c. URL : https://armypubs.army.mil/epubs/ DR_ pubs/DR_a/pdf/web/ARN16716_ATP\%203-

07x31\%20FINAL\%20WEB.pdf (дата звернення 04.09.2020).

28. Vego M., Bureaucratization of the Decisionmaking Process, JPME Today, JFQ 88, 1 st Quarter 2018, p. 34-45. URL : https://ndupress.ndu.edu/Publications/Article /1411771/the-bureaucratization-of-the-usmilitary-decisionmaking-process/ (дата звернення 07.09.2020).

29. Quick Introduction to Doctrine, U.S. Air Force Doctrine, 22 c. URL: https://www.doctrine.af. mil (дата звернення: 23.06.2020).

30. Marine Corps order 5600.20R, Marine Corps Doctrinal Publications System, Department of the Navy Headquarters United States Marine Corps, Washington DC, 18 June 2018, 10 c. URL : https://www.marines.mil/News/ Publica tions/MCPEL/ (дата звернення 07.09.2020).

31. OPNAV Instruction 5420.106A, NAVY Doctrine Development Policy, Department of the Navy Headquarters United States Marine Corps, Washington DC, 11 March 2013, 6 c. URL : https://www.secnav.navy.mil/doni/Directives/ 05000\%20General\%20Management \%20Security\%20and\%20Safety\%20Services/0 5-400\%200rganization\%20and\%20Functional \%20 Support\%20Services/5420.106A.pdf (дата звернення 07.09.2020).

32. Joint Doctrine Hierarchy Chart, July 2020, Joint Electronic Library, Joint Chiefs of Staff official website, URL : https://www.jcs.mil/Portals/36/ Documents/Doctrine/pubs/status.pdf?ver= 
2020-07-30-140030-920 (дата звернення 07.09.2020).

33. Air Land Sea Application Center Roadshow, Air Land Sea Application Center official website, URL : https://www.alsa.mil/Portals/9/ Documents/roadshow.pdf?ver= 2020-08-05163232-250 (дата звернення 07.09.2020).

34. Joint Pub 1-01.1, Compendium of Joint Publications, Department of Defence USA, 23 April 1999. URL : https://www.bits.de/ NRANEU/others/jp-doctrine/jp1_01_1.pdf, (дата звернення 04.09.2020, доктрина втратила чинність але має історичну інформацію).

35. Про питання військової стандартизації: наказ Міністерства оборони України від 24.02.2020 №56. Режим доступу: URL : https://zakon.rada.gov.ua/laws/show/z024020\#Text (дата звернення 09.09.2020).

36. Information management in NATO (Part one) How NATO Defines and Organizes Information Management, Strategies and its Point of View / Csanádi G. Applied Military Sciences - 2018 № 1 - cт. 136-158. URL : https://regi.honve delem.hu/files/files/112426/dr_2018_1_

beliv_angol_szemle.pdf\#page=138 (дата звернення 09.09.2020).

37. AJP-5 Allied Joint Doctrine for the planning of operations. Edition A Version 2 with UK national elements. North Atlantic Treaty Organization Allied Joint Publication, NATO Standardization Office (NSO), May 2019, 200 c.
URL : https://assets.publishing.service.gov.uk /government/uploads/system/uploads/attach ment_data/file/837082/dcdc_doctrine_nato_ planning_of_ops_ajp_5.pdf (дата звернення 09.06.2020).

38. Fixing Army Doctrine A Network Approach/ Tollefson J. // Military Review / 2018. - №1 c. 71-79. URL: http://cgsc.contentdm.oclc.org/ cdm/ref/collection/p124201coll1/id/1295 (дата звернення 15.09.2020).

39. Army Regulation 25-30 The Army Publishing Program. Headquarters Department of the Army Washington, DC, 27 March 2006, 104 c. URL : http://citeseerx.ist.psu.edu/viewdoc/ download?doi=10.1.1.125.3441\&rep=rep1\&ty pe=pdf (дата звернення 13.10.2020, Документ втратив чинність але містить історичну інформацію).

40. Army Regulation 25-30 The Army Publishing Program. Headquarters Department of the Army Washington, DC, 13 June 2018, 79 c. URL: https://armypubs.army.mil/epubs/DR_pubs/ DR_a/pdf/web/ARN17764_R_25_30_Admin_F INAL.pdf (дата звернення 13.10.2020).

41. Army Doctrinal Publication 1-02. Terms and Military Symbols. Headquarters Department of the Army Washington, DC, November 2019, 250 c. URL : https://armypubs.army.mil/epubs /DR_pubs/DR_a/pdf/web/ARN20083_ADP\%2 01-02\%20C1\%2OFINAL\%20WEB.pdf (дата звернення 15.10.2020).

\title{
Анализ основ и выработка рекомендаций по началу работы с системой доктринального обеспечения Сухопутных войск США в контексте приведения доктринального обеспечения Вооруженных Сил Украины к стандартам НАТО
}

\section{Виктор Российцев * А}

*Corresponding author: Старший преподаватель кафедры, e-mail: victor.rossiytsev@gmail.com, ORCID: 0000-0001-6176-0108

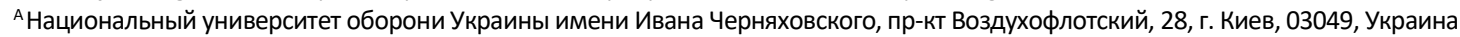

\begin{abstract}
Аннотация
Статья будет интересна для специалистов составляющих сил обороны, занимающихся их развитием и которые работают над изучением и внедрением современных стандартов и принципов ведущих стран НАТО. США является передовой страной НАТО и их вооруженные силы оказывают значительное влияние на современное состояние и перспективы этого военно-политического блока. Статья сфокусирована на доктринальном
\end{abstract}


обеспечения СВ США. По своему значению, Доктрины СВ США возможно приравнять к руководящими документами уровня отдельной составляющей сил обороны. Сейчас система доктринального обеспечения Сухопутных войск США открыта и находится в свободном доступе в сети интернет. Тысячи доктринальных и других военных руководящих публикаций СВ США дают исчерпывающий перечень ответов на вопросы о современных стандартах функционирования вооруженных сил в мирное и военное время. Спектр вопросов варьируется от порядка взаимодействия между различными составляющими сил обороны до принципов здорового питания и сна отдельного военнослужащего.

Статья написана в контексте реформы системы доктринального обеспечения Вооруженных Сил Украины. Реформа предусматривает разработку до конца 2020 года 272 новых доктринальных документов с учетом стандартов НАТО и опыта Операции Объединенных сил (Антитеррористической операции) на востоке Украины. Таким образом, перед разработчиками новых доктрин стоит задача в короткие сроки изучить и обобщить опыт ООС (АТО), требования как действующих национальных руководящих документов так и стандартам ведущих стран НАТО и подготовить на их основе такие доктринальные документы, которые позволят эффективно выполнять задачи возложенные на Вооруженные Силы Украины. Однако работа с доктринальными документами другой страны, кроме знания иностранного языка и соответствующей военной терминологии, требует понимания основ работы с доктриной соответствующего государства. Статья предоставляет минимальный набор знаний, который позволит начать уверенную работу с доктринальными публикациями СВ США и ускорить процесс их изучения.

Ключевые слова: доктрины, доктринальные публикации, руководящие документы СВ США, иерархия доктрин СВ США, основы доктрин СB США (ADP, ADRP, FM, ATP, JP, AJP, MTTP, MCDP, MCWP, MCTP, MCIP, NDP, NWP, NTTP , NTRP)

\title{
US Army doctrine foundations review and development of recommendations on initiation of US Army doctrinal studies for beginners in the context of Ukrainian Armed Forces transition towards NATO standards
}

\author{
Victor Rossiytsev * A \\ ${ }^{*}$ Corresponding author: Senior instructor of Department, e-mail: victor.rossiytsev@gmail.com, ORCID: 0000-0001-6176-0108 \\ A The National Defence University of Ukraine named after Ivan Cherniakhovskyi, 28, Povitroflotskyi Ave., Kyiv, 03049, Ukraine
}

\begin{abstract}
This article could be interesting for defense professionals engaged in research and implementation of modern standards and principles of leading NATO countries. The United States is a leading NATO country and its armed forces have a significant impact on the current state and prospects of this political-military alliance. The article focuses on the US Army doctrine which in terms of significance, could be equated to the smaller nation-level Armed Forces doctrinal publications.

Currently, the US Army doctrine is open and most part of it available for unrestricted access from the Internet. Thousands of doctrinal and other military publications provide an exhaustive list of answers on current standards of leading military forces functioning in peacetime and wartime environment. The range of themes varies from the interaction between the various components of the military forces and various civil agencies in unified operations to the holistic principles of healthy eating and work-sleep balance for an individual soldier.
\end{abstract}


This paper is written in the light of the full revision of the of the Ukrainian Armed Forces doctrine. The reform envisages the development of 272 brand new doctrinal publications by the end of 2020. These doctrines are to consider the lessons learned in Allied Forces Operation (AntiTerrorist Operation) in eastern Ukraine and the requirements of both existing national regulations and the standards of leading NATO member countries. Moreover, this reform must not to reduce the existing level of effectiveness of Armed Forces operations in the Eastern Ukraine.

Exploration of foreign doctrine, however, requires from the researcher not only proficiency in foreign language and relevant military terminology, but also the knowledge of the respective doctrinal foundations. This article offers a minimum set of knowledge that will allow researcher to confidently work with US Army doctrine and is to facilitate its further learning process.

Keywords: doctrine, doctrinal publications, US Army doctrine hierarchy, (ADP, ADRP, FM, ATP, JP, AJP, MTTP, MCDP, MCWP, MCTP, MCIP, NDP, NWP, NTTP, NTRP).

\section{References}

1. Zakon Ukrainy "Pro natsionalnu bezpeku Ukrainy" // URL: http://zakon.rada.gov.ua/ laws/show/2469-19?lang=en (retrieved 23.05.2020), [in Ukrainian].

2. Stratehichnyi oboronnyi biuleten Ukrainy: Ukaz Prezydenta Ukrainy vid 06.06.2016 № 240 Pro rishennia RNBO Ukrainy vid 20 travnia 2016 roku "Pro Stratehichnyi oboronnyi biuleten Ukrainy" // Ofitsiine internet-predstavnytstvo Prezydenta Ukrainy. URL: http://www. president.gov.ua/documents/2402016-20137 (retrieved 23.05.2020, in Ukrainian).

3. Pro zatverdzhennia Tymchasovoho poriadku oformlennia viiskovykh publikatsii u Zbroinykh Sylakh Ukrainy: nakaz Heneralnoho shtabu Zbroinykh Syl Ukrainy vid 26.12.2018 №460, personal archive, in Ukrainian.

4. TRADOC Regulation 25-36, The TRADOC Doctrine Publication Program, United States Army Training and Doctrine Command Fort Eustis, VA, 21 May, 2014, 82 p. URL : https://adminpubs.tradoc.army.mil/regulation s/TR25-36.pdf (retrieved 02.06.2020).

5. Army Doctrine Publication 3-0, Operations, Headquarters Department of the Army Washington, DC, July 2019, 102 p. URL : https://armypubs.army.mil/epubs/DR_pubs/D R_a/pdf/ web/ ARN18010_ADP\%2030\%2OFINAL\%20WEB.pdf (retrieved 02.06.2020).

6. Joint Doctrine Publication 05. Shaping a Stable World: the Military Contribution. The Development, Concepts and Doctrine Centre Ministry of Defence Shrivenham SWINDON,
Wiltshire, UK, March 2016, 102 p. URL : https://assets.publishing.service.gov.uk/gover nment/uploads/system/uploads/attachment_ data/file/516849/20160302-Stable_world_ JDP_05.pdf (retrieved 02.06.2020).

7. Joint Doctrine Publication 02. UK Operations: the Defence Contribution to Resilience and Security. The Development, Concepts and Doctrine Centre Ministry of Defence Shrivenham SWINDON, Wiltshire, UK, February 2017, 124 p. https://assets.publishing. service.gov.uk/ government/uploads/system/ uploads/attachment_data/file/591639/20170 207_JDP02_Resilience_web.pdf (retrieved 02.06.2020).

8. Oboronna reforma: systemnyi pidkhid do oboronnoho menedzhmentu: monohrafiia / A. Pavlikovskyi, V. Frolov, F. Sahaniuk ta in.; za zah. red. d. viisk. n. A. Syrotenka. K.: NUOU, 2020. 274p., [in Ukrainian].

9. Osnovy planuvannia operatsii za standartamy NATO : navch. posib. / [M. Hrebeniuk, S. Salkutsan, Yu. Ostakh, A. Shyhyda]. Kyiv : NUOU im. Ivana Cherniakhovskoho, 2015. - 120 p., [in Ukrainian].

10. Pohliady providnykh fakhivtsiv NATO na vohnevu pidtrymku z zakrytykh vohnevykh pozytsii: monohrafiia / [lu. Ye. Repilo, S. M. Salkutsan, O. M. Shevchenko ta in.]. Kyiv : NUOU, 2018. - 196 p., [in Ukrainian].

11. Analiz osnovnykh polozhen statutu bryhady viisk PPO Sukhoputnykh viisk zbroinykh syl SShA FM 3-01.7(3-01.11) / S.M. Piskunov, A.F. Volkov, Yu.O. Halkin, M.M. Brechka // Zbirnyk 
naukovykh prats Kharkivskoho natsionalnoho universytetu Povitrianykh Syl/ - 2019. - № 4(62). - pp. 68-73., DOI: 10.30748/zhups.2019.62.09, [in Ukrainian].

12. Pro orhanizatsiiu rozrobky doktrynalnykh dokumentiv Zbroinykh Syl Ukrainy: Dyrektyva Heneralnoho shtabu Zbroinykh Syl Ukrainy vid 13.03.2020 №D-6, personal archive, [in Ukrainian].

13. Army Doctrinal Publication 1-01. Doctrine primer. Headquarters Department of the Army Washington, DC, July 2019, 44 p. URL : https://armypubs.army.mil/epubs/DR_pubs/D R_a/pdf/web/ARN18138_ADP\%201-01\%20 FINAL \%20WEB.pdf (retrieved 02.06.2020).

14. Jackson A. Doctrine, Strategy and Military Culture: Military-Strategic Doctrine Development in Australia, Canada and New Zealand, 1987-2007 : Ottawa: Canadian Department of National Defense, 2013, 208 p.

15. Army Doctrine Publication 3-0 An Opportunity to Meet the Challenges of the Future / Ancker C., Scully M. // Military Review / 2013. - №1 pp.38-42. URL: http://cgsc.cdmhost.com/ cdm/ref/collection/p124201coll1/id/1191 (retrieved 02.06.2020).

16. Doctrine 2015 Information Briefing, United States Army Combined Arms Center. US Army Combined Arms Center (USACAC) Repository : web-site. URL: http://cgsc.contentdm.oclc. $\mathrm{org} / \mathrm{cdm} /$ singleitem/collection/p16040coll2/id /0 (retrieved 01.09.2020).

17. Field manual 1-02.01 Operational terms. Headquarters Department of the Army Washington, DC, November 2019, 160 p. URL : https://armypubs.army.mil/epubs/DR_pubs/D R_a/ pdf/web/ARN19780_FM\%201-02x1\%20\%20FINAL \%20WEB.pdf (retrieved 01.09.2020).

18. Army Regulation 5-22 Management The Army Force Modernization Proponent System. Headquarters Department of the Army Washington, DC, 20 October 2015, 19 p.: URL : https://armypubs.army.mil/epubs/DR_pubs/D R_a/pdf/web/r5_22.pdf (retrieved 02.09. 2020).

19. Field Manual 3-0. Operations. Headquarters Department of the Army Washington, DC, 6
October, 2017, 363 p.: URL : https://armypubs. us.army.mil/doctrine/fm3-0.pdf. (retrieved 02.09.2020).

20. Department of the Army Pamphlet 25-40 Army Publishing Program Procedures Headquarters Department of the Army Washington, DC, 13 June 2018, 198 p.: URL : https://armypubs.army.mil/epubs/DR_pubs/D R_a/pdf/web/ARN11758_P25_40_Admin_Fin al.pdf (retrieved 02.09.2020).

21. Doctrine Smart book, Combined Arms Doctrine Directorate, United States Army Combined Arms Center Fort Leavenworth, KS, June 2020, 120 p.: URL : https://caccapl.blob. core.usgovcloudapi.net/web/repository/pdffiles/doctrine-smartbook.pdf (retrieved 02.09.2020).

22. Joint Publication 1, Doctrine for the Armed Forces of the United States, Department of Defence USA, 25 March 2003: URL : https://www.jcs.mil/Portals/36/Documents/ Doctrine/pubs/jp1_ch1.pdf (retrieved 03.09.2020).

23. Joint Publication 3-16, Multinational Operations, Department of Defence USA, 1 March 2019: URL : https://www.jcs.mil/ Portals/36/Documents/Doctrine/pubs/jp3_16. pdf (retrieved 04.09.2020).

24. Field Manual 3-16. The Army in Multinational Operations, Headquarters Department of the Army Washington, DC, 8 April, 2014, 168 p.: URL : https://armypubs.army.mil/epubs/DR_ pubs/DR_a/pdf/web/fm3_16.pdf. (retrieved 04.09.2020).

25. CJCSM 5120.01A, Chairman of the Joint Chiefs of Staff Manual, Joint doctrine development process, Joint Staff Washington, DC, 29 December 2014, 131 p.: URL : https://www.jcs.mil/Portals/36/Documents/D octrine/pubs/cjcsm5120_01a.pdf (retrieved 04.09.2020).

26. APP-28, Allied Procedural Publication, Tactical planning for Land Forces. Edition A, Version 1, NATO Standard, NATO Standardization Office, NATO, 102 p., November 2019, personal archive.

27. Multi-service tactics, techniques, and procedures for Peace operations ATP 3-07.31 
MCTP 3-03B AFTTP 3-2.40, Air Land Sea Application (ALSA) Center, 2 May 2019, 132 p.: URL : https://armypubs.army.mil/epubs/ DR_pubs/DR_a/pdf/web/ARN16716_ATP\%20 3-07x31\%20FINAL\%20WEB.pdf (retrieved 04.09.2020).

28. Vego M., Bureaucratization of the Decisionmaking Process, JPME Today, JFQ 88, 1 st Quarter 2018, pp. 34-45.: URL : https://ndupress.ndu.edu/Publications/Article /1411771/the-bureaucratization-of-the-usmilitary-decisionmaking-process/ (retrieved 07.09.2020).

29. Quick Introduction to Doctrine, U.S. Air Force Doctrine, 22 p. URL: https://www.doctrine. af.mil (retrieved: 23.06.2020).

30. Marine Corps order 5600.20R, Marine Corps Doctrinal Publications System, Department of the Navy Headquarters United States Marine Corps, Washington DC, 18 June 2018, 10 p.: URL : https://www.marines.mil/News/Publica tions/MCPEL/ (retrieved 07.09.2020).

31. OPNAV Instruction 5420.106A, NAVY Doctrine Development Policy, Department of the Navy Headquarters United States Marine Corps, Washington DC, 11 March 2013, 6 p.: URL : https://www.secnav.navy.mil/doni/Directives/ 05000\%20General\%20Management\%20Secu rity\%20and\%20Safety\%20Services/05-400\% 200rganization\%20and\%20Functional\%20 Support\%20Services/5420.106A.pdf (retrieved 07.09.2020).

32. Joint Doctrine Hierarchy Chart, July 2020, Joint Electronic Library, Joint Chiefs of Staff official website: URL : https://www.jcs.mil/ Portals/ 36/Documents/Doctrine/pubs/status.pdf?ver =2020-07-30-140030-920 (retrieved 07.09. 2020).

33. Air Land Sea Application Center Roadshow, Air Land Sea Application Center official website: URL : https://www.alsa.mil/Portals/9/ Docume nts/roadshow.pdf?ver = 2020-08-05-163232250 (retrieved 07.09.2020).

34. Joint Pub 1-01.1, Compendium of Joint Publications, Department of Defence USA, 23 April 1999: URL : https://www.bits.de/ NRANEU/others/jp-doctrine/jp1_01_1.pdf, (retrieved 04.09.2020).

35. Pro pytannia viiskovoi standartyzatsii: nakaz Ministerstva Oborony Ukrainy vid 24.02.2020 №56: URL: https://zakon.rada.gov.ua/ laws/ show/z0240-20\#Text (retrieved 09.09.2020, in Ukrainian).

36. Information management in NATO (Part one) How NATO Defines and Organizes Information Management, Strategies and its Point of View / Csanádi G. Applied Military Sciences. 2018 № 1 - pp. 136-158.: URL: https://regi.honvedelem. hu/files/files/112426/dr_2018_1_beliv_ angol _szemle.pdf\#page=138 (retrieved 09.09.2020).

37. AJP-5 Allied Joint Doctrine for the planning of operations. Edition A Version 2 with UK national elements. North Atlantic Treaty Organization Allied Joint Publication, NATO Standardization Office (NSO), May 2019, 200 p.: URL: https://assets.publishing.service. gov.uk/government/uploads/system/uploads/ attachment_data/file/837082/dcdc_doctrine_ nato_planning_of_ops_ajp_5.pdf (retrieved 09.06.2020).

38. Fixing Army Doctrine A Network Approach/ Tollefson J. Military Review. 2018. №1 pp.7179. URL: http://cgsc.contentdm.oclc. org/ cdm/ref/collection/p124201coll1/id/1295 (retrieved 15.09.2020).

39. Army Regulation 25-30 The Army Publishing Program. Headquarters Department of the Army Washington, DC, 27 March 2006, 104 p.: URL : http://citeseerx.ist.psu.edu/viewdoc/ download?doi=10.1.1.125.3441\&rep=rep1\&ty pe $=$ pdf (retrieved 13.10.2020).

40. Army Regulation 25-30 The Army Publishing Program. Headquarters Department of the Army Washington, DC, 13 June 2018, 79 p. : URL: https://armypubs.army.mil/epubs/DR pubs/DR_a/pdf/web/ARN17764_R_25_30_Ad min_FINAL.pdf (retrieved 13.10.2020).

41. Army Doctrinal Publication 1-02. Terms and Military Symbols. Headquarters Department of the Army Washington, DC, November 2019, 250 p. URL : https://armypubs.army. mil/epubs/DR_pubs/DR_a/pdf/web/ARN2008 3_ADP\%201-02\%20C1\%2OFINAL\%20WEB.pdf (retrieved 15.10.2020). 